\title{
University Library Services and Student Academic Performance
}

Booysen Sabeho Tubulingane, Namibia University of Science and Technology, Windhoek, Namibia

\begin{abstract}
In many countries, university libraries are required to demonstrate quantitatively their value to their institutions. Consequently, many universities spend a large part of their institutional budgets on acquiring new library books, paying for high online journal subscription fees, and recruiting library staff. However, few studies have been conducted to evaluate the contribution of the university libraries to the students' success. Thus, this study, which applied a quantitative survey methodology to quantify the contribution of a Namibian university library to student academic performance, was conducted. The study determined the contribution of the university library services to students' academic performance. Additionally, the study established a relationship between students' library service satisfaction and academic performance. Analysis of library user satisfaction, student age, and gender were also examined.
\end{abstract}

\section{KEYWORDS}

Achievement, Age, Chi-Square, Cross Tabulation, Gender, Library Usage, Regression, Satisfaction

\section{INTRODUCTION}

\section{Background and Problem Statement}

There is a need for university libraries to demonstrate quantitatively their value to their institutions (Luther, 2008). Consequently, studies such as that of Lonsdale (2003) was conducted and revealed that a strong library program that is adequately staffed, resourced and funded can lead to higher student academic performance. Similarly, Wells' (1995) study established a positive relationship between academic achievement and the use of a number of different library resources or services. Brown and Malenfant (2015) also affirm that university libraries contribute to student learning and success. In addition, Ida (2016) demonstrated that students from schools with libraries with adequate relevant academic materials perform better than those from schools with no libraries. In light of these views, higher education institutions are encouraged to advance and refine strategies that focus on the library's contributions to universities' missions when it comes to student success (Brown \& Malenfant, 2015). The current study examines relationships between factors such as age, gender, library usage, and satisfaction and student academic performance. The expected research output is to produce a model that university managements can use to determine the value of the university libraries to its primary customers: students. 


\section{Research Objectives}

- To determine the contribution of library usage to student academic performance.

- To assess whether there is a relationship between library service satisfaction and student academic performance.

- To analyze library user satisfaction with reference to students' period of study, age and gender.

\section{Significance of the Study}

The study will quantify the role of a university library when it comes to student academic performance. The importance of ensuring good library customer service to students will be demonstrated by analyzing student academic performance outcomes. University libraries can use results of the research to convince their university management to continue investing in developing library academic resources. The study can be used as a benchmark by universities to model the value of their libraries based on the students' feedback in order to source for extra funding from other stakeholders such as the United Nations Educational, Scientific and Cultural Organization (UNESCO) who are involved globally in the development of the education system.

\section{STUDY FOCUS AREAS}

\section{Library Usage and Student Academic Performance}

In a modern educational system, access and usage of academic materials by students is very important for the success and academic achievement of the students (Nazy, Socheata, Sopanha \& Vichea, 2018). Consequently, it is imperative that students understand the value and take advantage of the benefits that a library can provide (Nazy et al., 2018). As such, libraries are set up in universities to enhance the academic performance of students (Gbemi-Ogunleye, 2016). The immediate implication is that students' access to electronic resources positively contributes to student academic performance (SulitLeonen, 2012). In their study, Ramsden and Stone (2013) established a positive association between student book borrowing and degree result, and electronic resource access and degree result. Using the same line of thought, Gbemi-Ogunleye (2016) also revealed a significant association between library usage and the students' academic achievement. In addition, de Jager (1997) supports this idea by observing that there is a positive relationship between the use of a library open shelf books and academic achievement. The assumption drawn from these scholarly views is that, as the frequency of library usage goes up, student academic performance is also likely to increase.

Conversely, Sulit-Leonen (2012) concluded that borrowing of books is statistically insignificant to student academic performance. This view is confirmed by Ramsden and Stone (2013) who note that, there is no association between library student entries/access and degree result. For instance, many students only go to the library to meet up with their friends and discuss things that are not academic related (Nazy et al., 2018). Similarly, Confessore, Lai, Ng and Zakaria (2016) discovered that non-academic-related activities showed statistically significant negative relationships with the students' academic performance.

\section{Library Service Satisfaction and Student Academic Performance}

In many cases library users, especially students, are highly dissatisfied with the library opening hours (Nawarathne \& Singh, 2013). Similarly, Aghojare, Ferdinand and Patrick (2015) revealed that students would like the library to stay open longer for them to have enough time to gain access to more educational materials that assist them in improving their academic performance. However, students' library satisfactions can vary within the university's faculties, schools or departments. For instance, Nawarathne and Singh (2013) observed that students from the Faculty of Management Studies were 
highly satisfied with the library services when compared to students from other faculties. According to Ateboh and Tiemo (2016), students are likely to be dissatisfied with the library reference materials and national and international journals in their subject areas especially when such materials are not up to date. Additionally, students indicated that there were inadequate books on the shelves, inadequate project materials and thesis collections in the library (Ateboh \& Tiemo, 2016). On the other hand, students were satisfied with lending services, renewal of library materials, and longer hours of internet services in the library, suitable opening hours, and downloading and printing of online resource services (Ateboh \& Tiemo, 2016).

\section{Library User Satisfaction, Student Period of Study, Age and Gender}

The distribution of undergraduate student library users of Government Hrangbana College based on year/period of study were as follows: $1^{\text {st }}$ year (31\%), $2^{\text {nd }}$ year $(36 \%)$ and $3^{\text {rd }}$ year (33\%) (Laltlanmawii $\&$ Verma, 2016). Gender wise, the distribution of students comprised of males as the majority with $59 \%$, while age-wise the distribution showed that $64 \%$ of the respondents belonged to the age group of 17-19 years (Laltlanmawii \& Verma, 2016). This indicates that $2^{\text {nd }}$ year students, particularly young males (aged 17-19 years old), articulate a higher rate of library usage than $1^{\text {st }}$ year library users. In another study by Niskala (2008), it was revealed that the majority of library users were female, young adults (aged 18-20 years) and were satisfied with the library services. Further, Laltlanmawii and Verma (2016), observed that most of the students were satisfied with the books, journals, print and online databases, and with collections of library materials. However, $51 \%$ of the students were not satisfied with the reference collections of the university library (Laltlanmawii \& Verma, 2016). The above statements intimate that younger students (aged between 17 and 19), are likely to be more satisfied with the library services than the older students, aged 20 years and above.

\section{STUDY APPROACH AND METHODOLOGY}

The study employed primarily a quantitative research design. An online self-administered structured questionnaire was developed to collect information from the student library users at a Namibian university. A random stratified sample of 372 students proportional to the number of students in each respective university faculty, period of study, age and gender was required from a population of 11226 students. The sample size was determined using Fluid Surveys (2014) and Smith's (2013) sample size formulae. The chi-square test and regression statistical techniques in Statistical Package for the Social Sciences (SPSS) software was used to model the relationship between age, gender, library frequent of usage, satisfaction and student academic performance. Students' consent to participate in the research was obtained before taking part in the study. Permission from the university management was obtained before conducting the study.

\section{RESULTS AND DISCUSSION}

\section{Age of Student and Academic Performance}

Based on the results of the linear regression model illustrated in Table 1, the R Square is 0.014, which means only $1.4 \%$ of the variation in student academic performance (Average mark in all semester 1 subjects) is a result of the influence of age. The standardized coefficient is -0.118 ; this highlights a very weak negative association between age and academic performance. The ANOVA results indicate that there is a very weak significant linear relationship between age and academic performance when testing at 95\% confidence level as the p-value is 0.001 (less than 5\%). Moreover, for the ANOVA results in Table 1, the residual sum of squares is equal to 163355.553 which translates to a proportion of $98.6 \%(163355.553 / 165673.405)$. This indicates 
Table 1. Regression results: age of student and academic performance

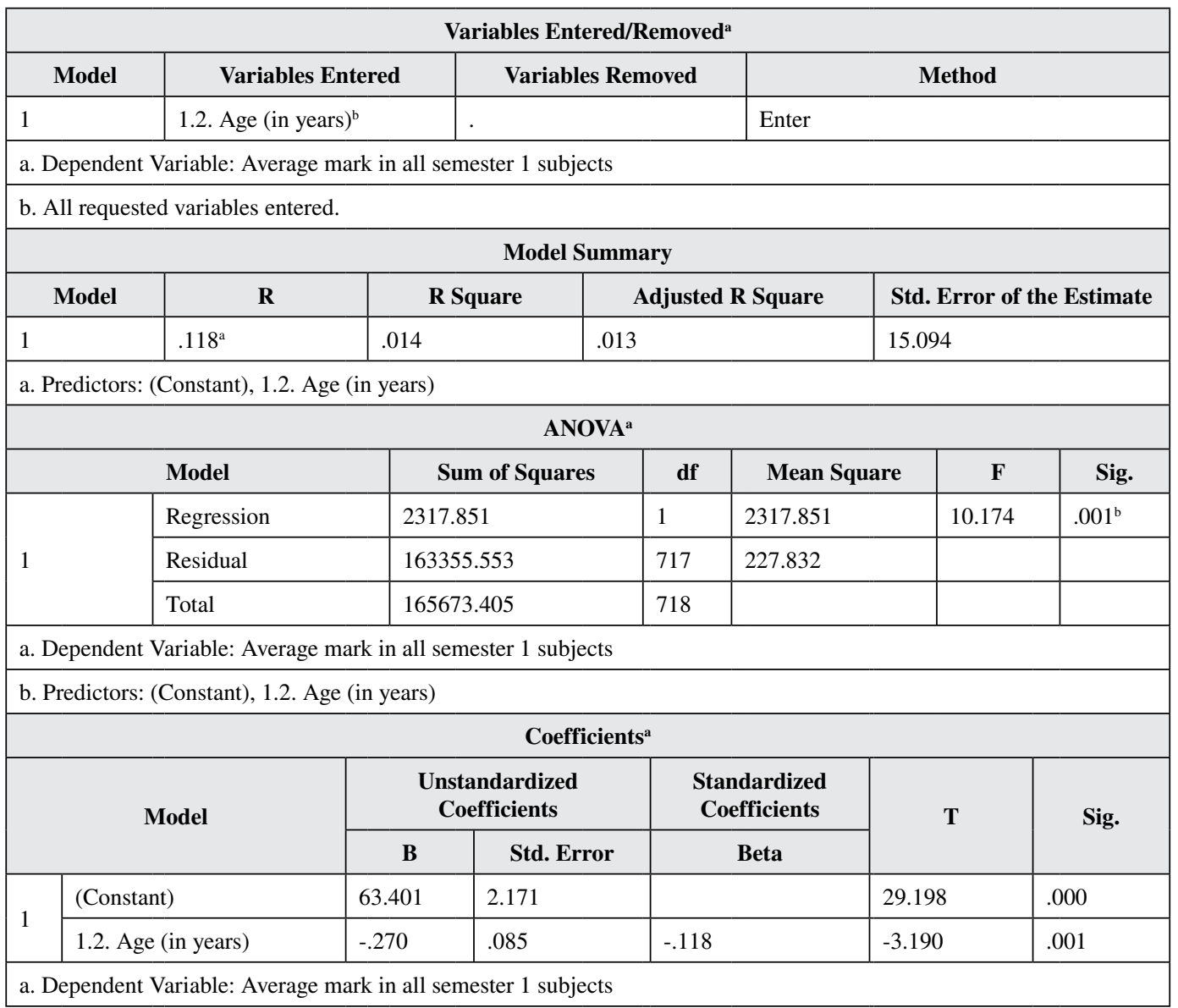

that $98.6 \%$ of the variation in student academic performance is attributed to errors or is due to other factors not considered in the model. The regression coefficient (B) is at -0.270 ; this indicates that for each unit increase in age, a decline of 0.270 units of academic performance is predicted by the model. This finding is in line with the student satisfaction results, as younger students (aged 17-19 years old) are highly satisfied. The finding also indicates that the younger students highly utilize libraries to improve their academic performance (Niskala, 2008).

\section{Gender and Academic Performance}

Table 2 provides a cross tabulation (crosstab) and chi-square test results which show that $56.5 \%$ of the failures are male students. Meanwhile, no differences are observed when it comes to the pass rate between males and females. The chi-square test results indicate that when testing at 0.05 significant level, there are no significant differences in academic performance attributed to gender as p-value (Asymptotic Significance (2-sided)) is more than 0.05 (0.166).

\section{Year of Study and Academic Performance}

Table 3 shows that $36.0 \%$ of the failures are students doing their first year. The chi-square test results indicate that there are no significant differences in academic performance attributed to year of study, as the p-value is more than $0.05(0.233)$. 
Table 2. Gender and academic performance

\begin{tabular}{|c|c|c|c|c|c|c|c|}
\hline \multicolumn{8}{|c|}{ Crosstab } \\
\hline & & & & & \multicolumn{2}{|c|}{ 1.1. Gender } & \multirow{2}{*}{ Total } \\
\hline & & & & & Female & Male & \\
\hline \multirow{4}{*}{$\begin{array}{l}\text { Passed semester or } \\
\text { failed }\end{array}$} & \multirow{2}{*}{ Fail } & \multicolumn{3}{|l|}{ Count } & 60 & 78 & 138 \\
\hline & & \multicolumn{3}{|c|}{$\%$ within Passed semester or failed } & $43.5 \%$ & $56.5 \%$ & $100 \%$ \\
\hline & \multirow{2}{*}{ Pass } & \multicolumn{3}{|l|}{ Count } & 307 & 307 & 614 \\
\hline & & \multicolumn{3}{|c|}{$\%$ within Passed semester or failed } & $50.0 \%$ & $50.0 \%$ & $100 \%$ \\
\hline \multirow{2}{*}{ Total } & & \multicolumn{3}{|l|}{ Count } & 367 & 385 & 752 \\
\hline & & \multicolumn{3}{|c|}{$\%$ within Passed semester or failed } & $48.8 \%$ & $51.2 \%$ & $100 \%$ \\
\hline \multicolumn{8}{|c|}{ Chi-Square Tests } \\
\hline & & Value & Df & \multicolumn{4}{|c|}{ Asymptotic Significance (2-sided) } \\
\hline Pearson Chi-Square & & $1.918^{\mathrm{a}}$ & 1 & \multicolumn{3}{|l|}{.166} & \\
\hline $\mathrm{N}$ of Valid Cases & & 752 & & & & & \\
\hline
\end{tabular}

Table 3. Year of study and academic performance

\begin{tabular}{|c|c|c|c|c|c|c|c|c|c|c|}
\hline \multicolumn{11}{|c|}{ Crosstab } \\
\hline & & & \multicolumn{7}{|c|}{ 1.3. Year of Study } & \multirow{2}{*}{ Total } \\
\hline & & & $\mathbf{0}$ & 1 & 2 & 3 & 4 & 5 & 6 & \\
\hline \multirow{4}{*}{$\begin{array}{l}\text { Passed } \\
\text { semester } \\
\text { or failed }\end{array}$} & \multirow[b]{2}{*}{ Fail } & Count & 2 & 50 & 32 & 37 & 12 & 5 & 1 & 139 \\
\hline & & $\begin{array}{l}\% \text { within Passed } \\
\text { semester or failed }\end{array}$ & $1.4 \%$ & $36.0 \%$ & $23.0 \%$ & $26.6 \%$ & $8.6 \%$ & $3.6 \%$ & $0.7 \%$ & $100 \%$ \\
\hline & \multirow[b]{2}{*}{ Pass } & Count & 3 & 220 & 145 & 144 & 76 & 28 & 0 & 616 \\
\hline & & $\begin{array}{l}\% \text { within Passed } \\
\text { semester or failed }\end{array}$ & $0.5 \%$ & $35.7 \%$ & $23.5 \%$ & $23.4 \%$ & $12.3 \%$ & $4.5 \%$ & $0.0 \%$ & $100 \%$ \\
\hline \multirow{2}{*}{\multicolumn{2}{|c|}{ Total }} & Count & 5 & 270 & 177 & 181 & 88 & 33 & 1 & 755 \\
\hline & & $\begin{array}{l}\% \text { within Passed } \\
\text { semester or failed }\end{array}$ & $0.7 \%$ & $35.8 \%$ & $23.4 \%$ & $24.0 \%$ & $11.7 \%$ & $4.4 \%$ & $0.1 \%$ & $100 \%$ \\
\hline \multicolumn{11}{|c|}{ Chi-Square Tests } \\
\hline & & & Value & \multicolumn{2}{|c|}{ df } & \multicolumn{5}{|c|}{ Asymptotic Significance (2-sided) } \\
\hline \multicolumn{3}{|c|}{ Pearson Chi-Square } & $8.064^{\mathrm{a}}$ & \multicolumn{2}{|l|}{6} & \multicolumn{5}{|l|}{.233} \\
\hline \multicolumn{3}{|c|}{$\mathrm{N}$ of Valid Cases } & 755 & & & & & & & \\
\hline
\end{tabular}

\section{Library Service Types and Academic Performance}

Table 4 indicates that $45.7 \%$ of the failures and $49.4 \%$ of the students who passed their semester 1 examinations rated the services at the circulation desk "Good." However, the differences in the students' ratings are insignificant as $\mathrm{p}$-value in the chi-square results is 0.460 . This finding is corroborated by Ateboh and Tiemo (2016) who revealed that the majority of the students are likely to be satisfied with lending services and renewal of library materials. Hence, there is no significant differences in terms of student library circulation desk service satisfaction based on the academic performance. 
Table 4. Passed semester or failed * 2.1. How would you describe the services at the Circulation Desk on Level 3 where you take out books as well as return them?

\begin{tabular}{|c|c|c|c|c|c|c|c|c|c|}
\hline \multicolumn{10}{|c|}{ Crosstab } \\
\hline & & & & \multicolumn{5}{|c|}{$\begin{array}{l}\text { 2.1. How would you describe the services at the } \\
\text { Circulation Desk on Level } 3 \text { where you take out books } \\
\text { as well as return them? }\end{array}$} & \multirow[t]{2}{*}{ Total } \\
\hline & & & & Very bad & Poor & Average & Good & Excellent & \\
\hline \multirow{4}{*}{$\begin{array}{l}\text { Passed } \\
\text { semester or } \\
\text { failed }\end{array}$} & \multirow[b]{2}{*}{ Fail } & \multicolumn{2}{|l|}{ Count } & 1 & 4 & 27 & 53 & 31 & 116 \\
\hline & & \multicolumn{2}{|l|}{$\begin{array}{l}\% \text { within Passed } \\
\text { semester or failed }\end{array}$} & $0.9 \%$ & $3.4 \%$ & $23.3 \%$ & $45.7 \%$ & $26.7 \%$ & $100 \%$ \\
\hline & & \multicolumn{2}{|l|}{ Count } & 2 & 10 & 139 & 252 & 107 & 510 \\
\hline & Pass & \multicolumn{2}{|l|}{$\begin{array}{l}\% \text { within Passed } \\
\text { semester or failed }\end{array}$} & $0.4 \%$ & $2.0 \%$ & $27.3 \%$ & $49.4 \%$ & $21.0 \%$ & $100 \%$ \\
\hline \multirow{2}{*}{\multicolumn{2}{|c|}{ Total }} & \multicolumn{2}{|l|}{ Count } & 3 & 14 & 166 & 305 & 138 & 626 \\
\hline & & \multicolumn{2}{|l|}{$\begin{array}{l}\% \text { within Passed } \\
\text { semester or failed }\end{array}$} & $0.5 \%$ & $2.2 \%$ & $26.5 \%$ & $48.7 \%$ & $22.0 \%$ & $100 \%$ \\
\hline \multicolumn{10}{|c|}{ Chi-Square Tests } \\
\hline & & & \multicolumn{2}{|c|}{ Value } & Df & \multicolumn{4}{|c|}{ Asymptotic Significance (2-sided) } \\
\hline \multicolumn{3}{|c|}{ Pearson Chi-Square } & \multicolumn{2}{|c|}{$3.618^{\mathrm{a}}$} & & \multicolumn{4}{|l|}{.460} \\
\hline \multicolumn{3}{|c|}{$\mathrm{N}$ of Valid Cases } & \multicolumn{2}{|l|}{626} & & & & & \\
\hline
\end{tabular}

Table 5 indicates that the majority (47\%) of the failures and $42.1 \%$ of the students who passed rated services at the short loan section "Good." However, the differences in the students' ratings are not significantly different as p-value in the chi-square results is 0.641 . Thus, there is no significant difference in terms of student short loan service satisfaction based on the academic performance.

Table 6 provides results of the ENCORE library service, an Online Public Access Catalogue (OPAC) that enables students to do searches and see what resources are available at the university library). The results reveal that the majority of the students (34.1\%) who passed are not sure (neither) whether it is easy for them to use ENCORE to renew items, place items on hold or search for books. Nevertheless, the differences in the students' ratings are not significantly different as p-value in the chi-square results is 0.296 . Consequently, there is no significant difference in terms of students using ENCORE service based on academic performance. The students' perceptions on the use of "ENCORE" are the same for those who passed or failed.

Table 7 reveals that the majority of students who passed at $30.7 \%$ indicated that it is easy for them to find the booking a venue service. However, the differences in the students' ratings are not significantly different as p-value in the chi-square results is 0.522 . Thus, there is no significant difference based on academic performance in terms of how easy students access the booking a venue library service.

Table 8 reveals that the majority of students who passed at $13.8 \%$ chose "Very easy" for the finding books on the library shelves option. A minimal per cent at $9.6 \%$ of students who failed also indicated that it is very easy to find books on the library shelves. The chi square results in Table 8 highlight a significant difference in the students' ratings for finding books on the library shelves based on academic performance. The p-value in the chi-square results is 0.047 , which is less than 0.05 . One may thus conclude that finding books on the library shelves is very important as it positively influences the students' academic performance. 
Table 5. Passed semester or failed * 2.2. How would you describe the services at Short Loan on Level 4 where you take out prescribed books for two hours?

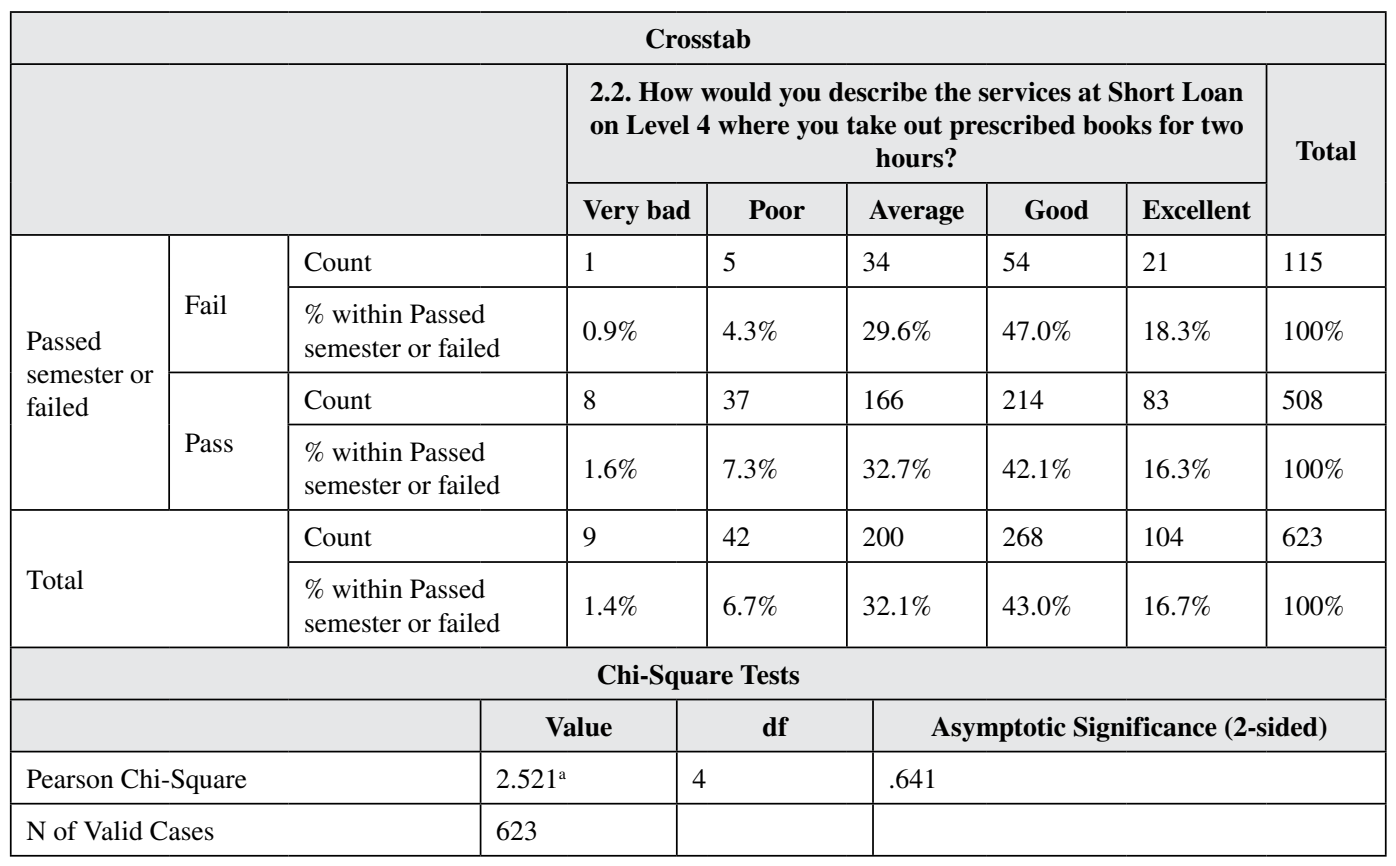

Table 6. Passed semester or failed * 2.3. Please indicate how easy you find using ENCORE to renew items, place items on hold or search for books.

\begin{tabular}{|c|c|c|c|c|c|c|c|c|c|}
\hline \multicolumn{10}{|c|}{ Crosstab } \\
\hline & & & & \multicolumn{5}{|c|}{$\begin{array}{l}\text { 2.3. Please indicate how easy you find using ENCORE to } \\
\text { renew items, place items on hold or search for books. }\end{array}$} & \multirow{2}{*}{ Total } \\
\hline & & & & $\begin{array}{c}\text { Very } \\
\text { difficult }\end{array}$ & Difficult & Neither & Easy & $\begin{array}{l}\text { Very } \\
\text { easy }\end{array}$ & \\
\hline \multirow{4}{*}{$\begin{array}{l}\text { Passed } \\
\text { semester } \\
\text { or failed }\end{array}$} & \multirow[b]{2}{*}{ Fail } & \multicolumn{2}{|l|}{ Count } & 9 & 27 & 31 & 34 & 16 & 117 \\
\hline & & \multicolumn{2}{|l|}{$\begin{array}{l}\% \text { within Passed } \\
\text { semester or failed }\end{array}$} & $7.7 \%$ & $23.1 \%$ & $26.5 \%$ & $29.1 \%$ & $13.7 \%$ & $100 \%$ \\
\hline & & \multicolumn{2}{|l|}{ Count } & 31 & 81 & 173 & 155 & 67 & 507 \\
\hline & Pass & \multicolumn{2}{|l|}{$\begin{array}{l}\% \text { within Passed } \\
\text { semester or failed }\end{array}$} & $6.1 \%$ & $16.0 \%$ & $34.1 \%$ & $30.6 \%$ & $13.2 \%$ & $100 \%$ \\
\hline \multirow{2}{*}{\multicolumn{2}{|c|}{ Total }} & \multicolumn{2}{|l|}{ Count } & 40 & 108 & 204 & 189 & 83 & 624 \\
\hline & & \multicolumn{2}{|l|}{$\begin{array}{l}\% \text { within Passed } \\
\text { semester or failed }\end{array}$} & $6.4 \%$ & $17.3 \%$ & $32.7 \%$ & $30.3 \%$ & $13.3 \%$ & $100 \%$ \\
\hline \multicolumn{10}{|c|}{ Chi-Square Tests } \\
\hline & & & \multicolumn{2}{|c|}{ Value } & df & \multicolumn{4}{|c|}{ Asymptotic Significance (2-sided) } \\
\hline \multicolumn{3}{|c|}{ Pearson Chi-Square } & \multicolumn{2}{|c|}{$4.917^{\mathrm{a}}$} & & \multicolumn{4}{|l|}{.296} \\
\hline \multicolumn{3}{|c|}{$\mathrm{N}$ of Valid Cases } & \multicolumn{2}{|l|}{624} & & & & & \\
\hline
\end{tabular}


Table 7. Passed semester or failed * 2.4. Please indicate how easy you find booking a venue.

\begin{tabular}{|c|c|c|c|c|c|c|c|c|c|}
\hline \multicolumn{10}{|c|}{ Crosstab } \\
\hline & & & & \multicolumn{5}{|c|}{$\begin{array}{l}\text { 2.4. Please indicate how easy you find booking a } \\
\text { venue. }\end{array}$} & \multirow{2}{*}{ Total } \\
\hline & & & & \multirow{2}{*}{$\begin{array}{l}\begin{array}{c}\text { Very } \\
\text { difficult }\end{array} \\
6\end{array}$} & Difficult & Neither & Easy & $\begin{array}{l}\text { Very } \\
\text { easy }\end{array}$ & \\
\hline \multirow{4}{*}{$\begin{array}{l}\text { Passed } \\
\text { semester or } \\
\text { failed }\end{array}$} & \multirow[b]{2}{*}{ Fail } & \multicolumn{2}{|l|}{ Count } & & 25 & 36 & 38 & 11 & 116 \\
\hline & & \multicolumn{2}{|l|}{$\begin{array}{l}\% \text { within Passed } \\
\text { semester or failed }\end{array}$} & $5.2 \%$ & $21.6 \%$ & $31.0 \%$ & $32.8 \%$ & $9.5 \%$ & $100 \%$ \\
\hline & \multirow[b]{2}{*}{ Pass } & \multicolumn{2}{|l|}{ Count } & 42 & 99 & 143 & 157 & 71 & 512 \\
\hline & & \multicolumn{2}{|l|}{$\begin{array}{l}\% \text { within Passed } \\
\text { semester or failed }\end{array}$} & $8.2 \%$ & $19.3 \%$ & $27.9 \%$ & $30.7 \%$ & $13.9 \%$ & $100 \%$ \\
\hline \multirow{2}{*}{\multicolumn{2}{|c|}{ Total }} & \multicolumn{2}{|l|}{ Count } & 48 & 124 & 179 & 195 & 82 & 628 \\
\hline & & \multicolumn{2}{|l|}{$\begin{array}{l}\% \text { within Passed } \\
\text { semester or failed }\end{array}$} & $7.6 \%$ & $19.7 \%$ & $28.5 \%$ & $31.1 \%$ & $13.1 \%$ & $100 \%$ \\
\hline \multicolumn{10}{|c|}{ Chi-Square Tests } \\
\hline & & & Value & \multicolumn{2}{|c|}{ df } & \multicolumn{4}{|c|}{ Asymptotic Significance (2-sided) } \\
\hline \multicolumn{3}{|c|}{ Pearson Chi-Square } & $3.217^{\mathrm{a}}$ & \multicolumn{2}{|l|}{4} & \multicolumn{4}{|c|}{522} \\
\hline \multicolumn{3}{|c|}{$\mathrm{N}$ of Valid Cases } & 628 & & & & & & \\
\hline
\end{tabular}

Table 8. Passed semester or failed * 2.5 . Please indicate how easy it is finding books on the shelves.

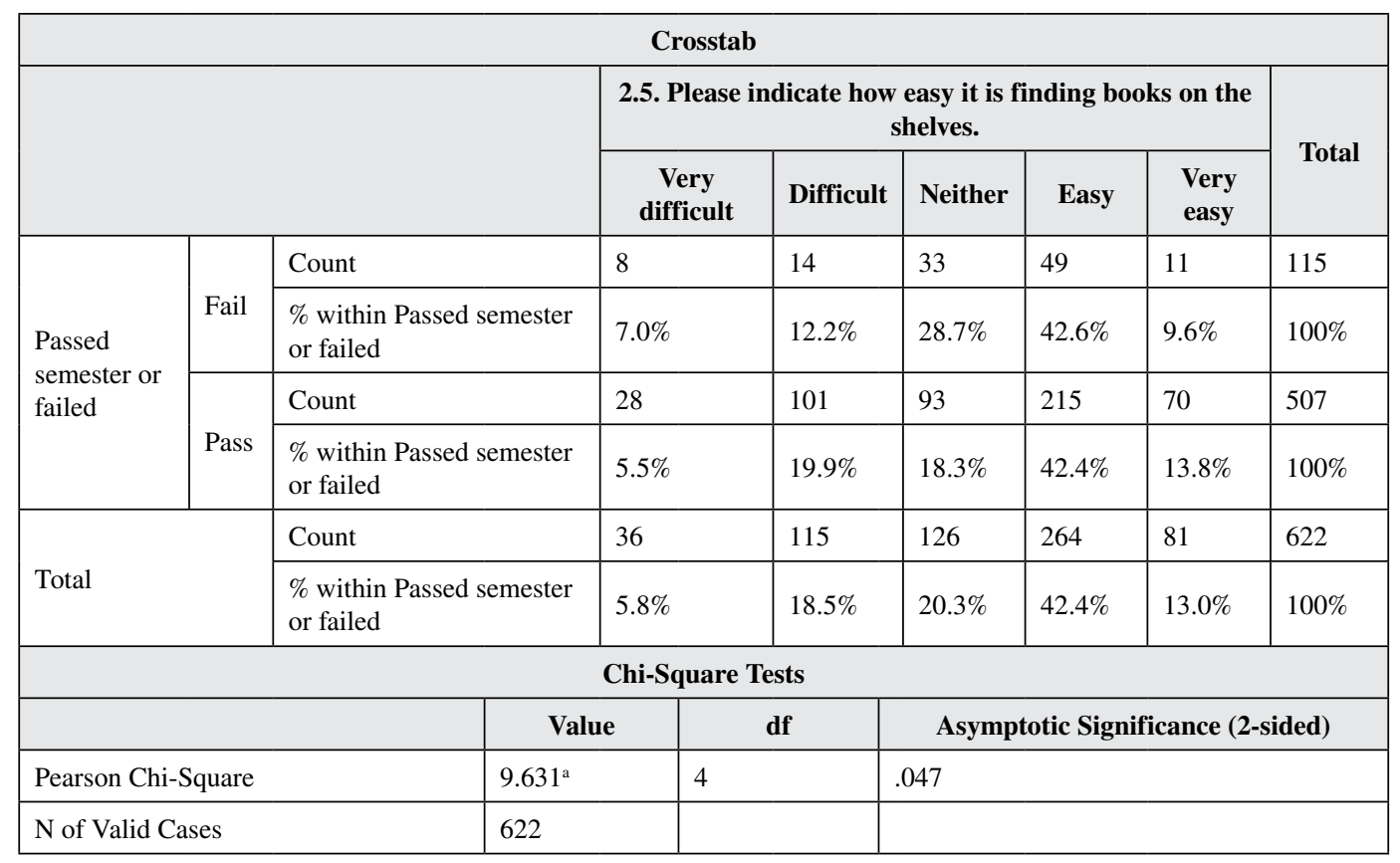


Table 9 reveals that the majority of the students who failed at $28.8 \%$ are not sure (rated average) of their experience of the Wi-Fi facilities in the library. Even so, no significant differences are observed at 0.05 significance level. The p-value is 0.552 for student Wi-Fi satisfaction results per academic performance. This indicates that access to the $\mathrm{Wi}-\mathrm{Fi}$ has no influence on the academic performance.

Table 10 reveals that the majority of the students regardless of whether they passed or failed use the library on a weekly basis. Thus, there are no significant differences in the students' ratings as $\mathrm{p}$-value in the chi-square results is 0.603 . This indicates that frequency of library use is not connected to student academic performance. This result contradicts findings by Gbemi-Ogunleye (2016) who discovered a significant positive relationship between library usage and the students' academic achievement. However, the results concur with Ramsden and Stone (2013) who established that there is no association between library usage frequency and academic performance.

Table 11 reflects that the majority of the students who passed at $57.7 \%$ are satisfied with the library building; and $57.9 \%$ of those who failed are also satisfied. Hence, because of the same trend in the satisfaction level between students who passed or failed, no significant differences are observed, as the p-value in the chi-square results is 0.931 .

Table 12 reveals that both the students who failed at $51.8 \%$ and $58.1 \%$ of those who passed are satisfied with the library seating arrangements. Nevertheless, the differences in students' ratings are not significantly different at 0.05 significance level, as p-value in the chi-square results is 0.100 .

Table 13 reveals that the majority of the students who passed at $62.5 \%$ and the $56.6 \%$ who failed are satisfied with the library lights. The students' ratings of the lighting in the library result show no significant difference at 0.05 significance level (as p-value is 0.310 ), based on the academic performance.

Table 14 indicates that the majority of the students who passed at $56.1 \%$, and the $53.1 \%$ who failed are satisfied with the library air-conditioning system. According to this result, the differences in the students' ratings are not significantly different as p-value in the chi-square results is 0.433 . Therefore, there is no significant difference based on the academic performance in terms of the students' satisfaction with the library air-conditioning.

Table 9. Passed semester or failed * 2.6. How do you rate the Wi-Fi facilities in the library?

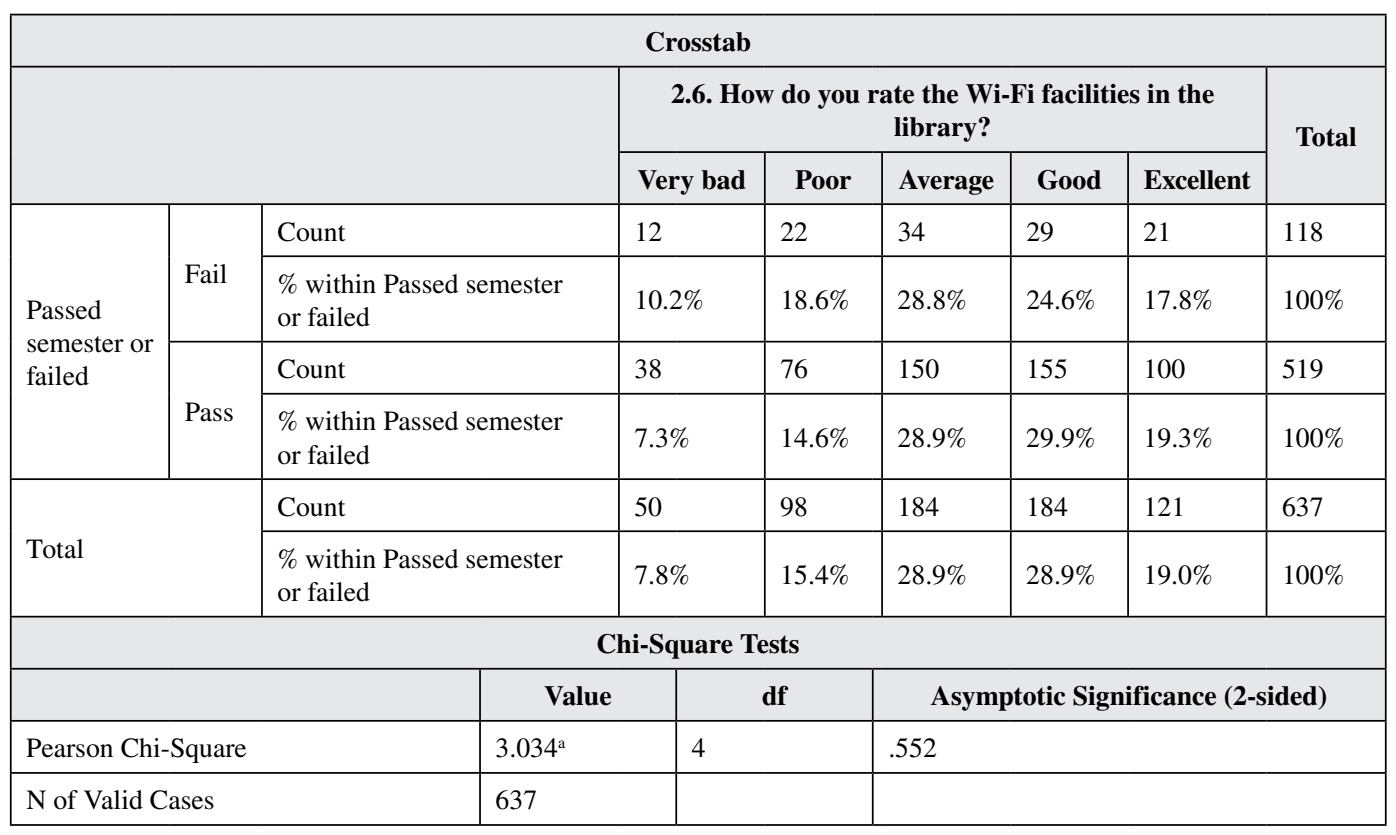


Table 10. Passed semester or failed * 2.7. How often do you use Library services?

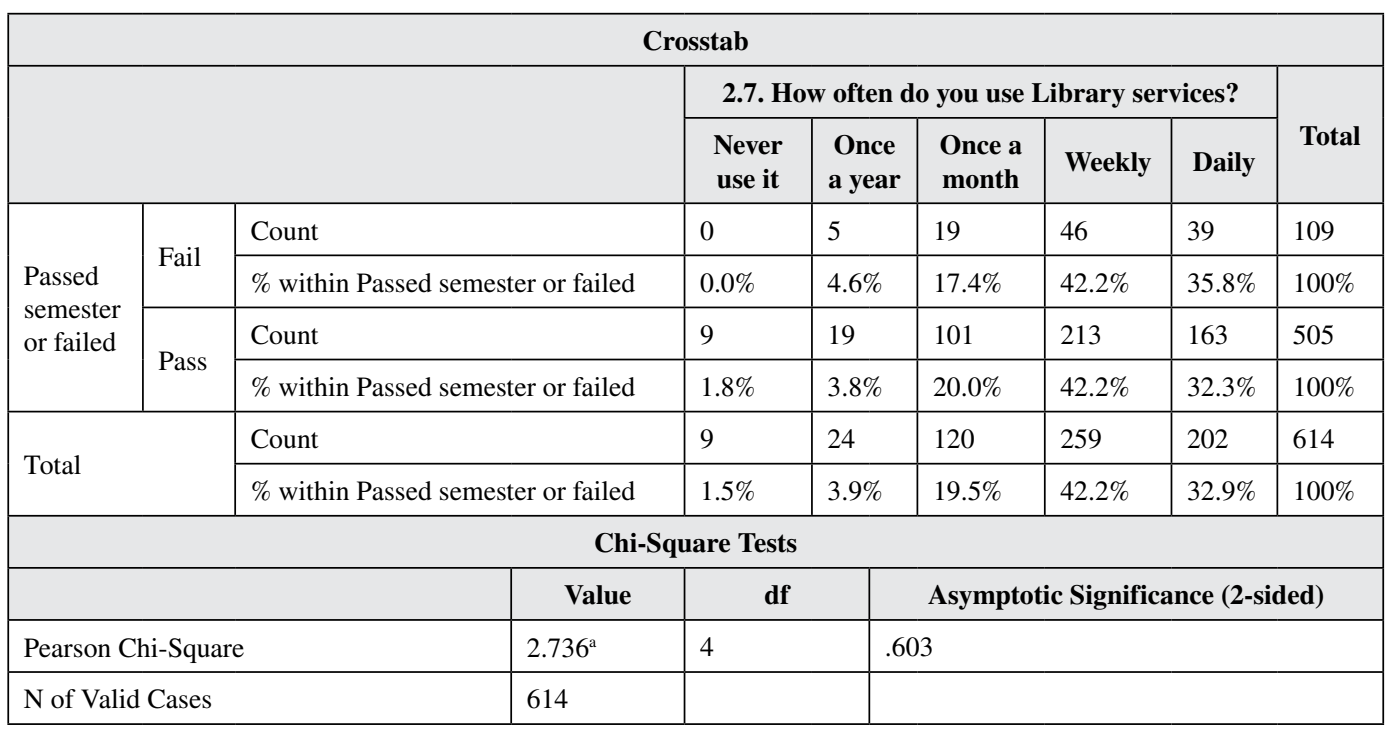

Table 11. Passed semester or failed * 3.1. Library building

\begin{tabular}{|c|c|c|c|c|c|c|c|c|}
\hline \multicolumn{9}{|c|}{ Crosstab } \\
\hline & & & & \multicolumn{4}{|c|}{ 3.1. Library building } & \multirow[b]{2}{*}{ Total } \\
\hline & & & & Dissatisfied & Neither & Satisfied & $\begin{array}{c}\text { Very } \\
\text { Satisfied }\end{array}$ & \\
\hline \multirow{4}{*}{$\begin{array}{l}\text { Passed } \\
\text { semester } \\
\text { or failed }\end{array}$} & \multirow{2}{*}{ Fail } & \multicolumn{2}{|c|}{ Count } & 4 & 8 & 66 & 36 & 114 \\
\hline & & \multicolumn{2}{|c|}{$\%$ within Passed semester or failed } & $3.5 \%$ & $7.0 \%$ & $57.9 \%$ & $31.6 \%$ & $100 \%$ \\
\hline & \multirow{2}{*}{ Pass } & \multicolumn{2}{|c|}{ Count } & 13 & 32 & 290 & 168 & 503 \\
\hline & & \multicolumn{2}{|c|}{$\%$ within Passed semester or failed } & $2.6 \%$ & $6.4 \%$ & $57.7 \%$ & $33.4 \%$ & $100 \%$ \\
\hline \multirow{2}{*}{\multicolumn{2}{|c|}{ Total }} & \multicolumn{2}{|c|}{ Count } & 17 & 40 & 356 & 204 & 617 \\
\hline & & \multicolumn{2}{|c|}{$\%$ within Passed semester or failed } & $2.8 \%$ & $6.5 \%$ & $57.7 \%$ & $33.1 \%$ & $100 \%$ \\
\hline \multicolumn{9}{|c|}{ Chi-Square Tests } \\
\hline & & & Value & Df & \multicolumn{4}{|c|}{ Asymptotic Significance (2-sided) } \\
\hline \multicolumn{3}{|c|}{ Pearson Chi-Square } & $.444^{\mathrm{a}}$ & 3 & \multicolumn{4}{|l|}{.931} \\
\hline \multicolumn{3}{|c|}{$\mathrm{N}$ of Valid Cases } & 617 & & & & & \\
\hline
\end{tabular}

Table 15 discloses that the majority of the students who passed or failed at $44.7 \%$ and $38.4 \%$, respectively are satisfied with the library lifts. P-value in Table 15 is 0.58 , which is higher than 0.05 , thus, no significant differences exist in student library lift satisfaction based on the academic performance.

Table 16 unveils that the majority of the students who passed or failed at $33.8 \%$ and $29.5 \%$ respectively are satisfied with the library overnight study area. The outcome in Table 16 shows a p-value of 0.430 , which is higher than 0.05 hence, no significant differences in student library overnight study area satisfaction exist based on the academic performance. 
Table 12. Passed semester or failed * 3.2. Seating arrangement

\begin{tabular}{|c|c|c|c|c|c|c|c|c|}
\hline \multicolumn{9}{|c|}{ Crosstab } \\
\hline & & & \multicolumn{5}{|c|}{ 3.2. Seating arrangement } & \multirow[b]{2}{*}{ Total } \\
\hline & & & $\begin{array}{c}\text { Very } \\
\text { dissatisfied }\end{array}$ & Dissatisfied & Neither & Satisfied & $\begin{array}{c}\text { Very } \\
\text { Satisfied }\end{array}$ & \\
\hline \multirow{4}{*}{$\begin{array}{l}\text { Passed } \\
\text { semester } \\
\text { or failed }\end{array}$} & \multirow[b]{2}{*}{ Fail } & Count & 2 & 20 & 17 & 59 & 16 & 114 \\
\hline & & $\begin{array}{l}\% \text { within Passed } \\
\text { semester or failed }\end{array}$ & $1.8 \%$ & $17.5 \%$ & $14.9 \%$ & $51.8 \%$ & $14.0 \%$ & $100 \%$ \\
\hline & \multirow{2}{*}{ Pass } & Count & 13 & 46 & 65 & 291 & 86 & 501 \\
\hline & & $\begin{array}{l}\% \text { within Passed } \\
\text { semester or failed }\end{array}$ & $2.6 \%$ & $9.2 \%$ & $13.0 \%$ & $58.1 \%$ & $17.2 \%$ & $100 \%$ \\
\hline \multirow{2}{*}{\multicolumn{2}{|c|}{ Total }} & Count & 15 & 66 & 82 & 350 & 102 & 615 \\
\hline & & $\begin{array}{l}\% \text { within Passed } \\
\text { semester or failed }\end{array}$ & $2.4 \%$ & $10.7 \%$ & $13.3 \%$ & $56.9 \%$ & $16.6 \%$ & $100 \%$ \\
\hline \multicolumn{9}{|c|}{ Chi-Square Tests } \\
\hline & & & Value & df & \multicolumn{4}{|c|}{ Asymptotic Significance (2-sided) } \\
\hline \multicolumn{3}{|c|}{ Pearson Chi-Square } & $7.784^{\mathrm{a}}$ & & \multicolumn{4}{|l|}{.100} \\
\hline \multicolumn{3}{|c|}{$\mathrm{N}$ of Valid Cases } & 615 & & & & & \\
\hline
\end{tabular}

Table 13. Passed semester or failed * 3.3. Lighting

\begin{tabular}{|c|c|c|c|c|c|c|c|c|}
\hline \multicolumn{9}{|c|}{ Crosstab } \\
\hline & & & \multicolumn{5}{|c|}{ 3.3. Lighting } & \multirow[b]{2}{*}{ Total } \\
\hline & & & $\begin{array}{c}\text { Very } \\
\text { dissatisfied }\end{array}$ & Dissatisfied & Neither & Satisfied & $\begin{array}{c}\text { Very } \\
\text { Satisfied }\end{array}$ & \\
\hline \multirow{4}{*}{$\begin{array}{l}\text { Passed } \\
\text { semester } \\
\text { or failed }\end{array}$} & \multirow{2}{*}{ Fail } & Count & 0 & 2 & 13 & 64 & 34 & 113 \\
\hline & & $\%$ within Passed semester or failed & $0.0 \%$ & $1.8 \%$ & $11.5 \%$ & $56.6 \%$ & $30.1 \%$ & $100 \%$ \\
\hline & & Count & 1 & 3 & 35 & 315 & 150 & 504 \\
\hline & & $\%$ within Passed semester or failed & $0.2 \%$ & $0.6 \%$ & $6.9 \%$ & $62.5 \%$ & $29.8 \%$ & $100 \%$ \\
\hline \multirow{2}{*}{\multicolumn{2}{|c|}{ Total }} & Count & 1 & 5 & 48 & 379 & 184 & 617 \\
\hline & & $\%$ within Passed semester or failed & $0.2 \%$ & $0.8 \%$ & $7.8 \%$ & $61.4 \%$ & $29.8 \%$ & $100 \%$ \\
\hline \multicolumn{9}{|c|}{ Chi-Square Tests } \\
\hline & & Value & df & \multicolumn{5}{|c|}{ Asymptotic Significance (2-sided) } \\
\hline \multicolumn{3}{|c|}{ Pearson Chi-Square } & 4 & \multicolumn{5}{|l|}{.310} \\
\hline \multicolumn{3}{|c|}{$\mathrm{N}$ of Valid Cases } & & & & & & \\
\hline
\end{tabular}

Table 17 reveals that the majority of students who passed at $49 \%$ are satisfied with the library signage while $40.5 \%$ of the students who failed are also satisfied. The similar result between the students who passed and those who failed results in a no significant difference (at 0.05) in terms of library signage satisfaction based on the academic performance as p-value in Table 17 is 0.130 .

Table 18 discloses that the majority of the students who passed or failed at $54.4 \%$ and $59.8 \%$, respectively agree that overall, they always have a positive experience in the library. 
Table 14. Passed semester or failed * 3.4 . Air-conditioning

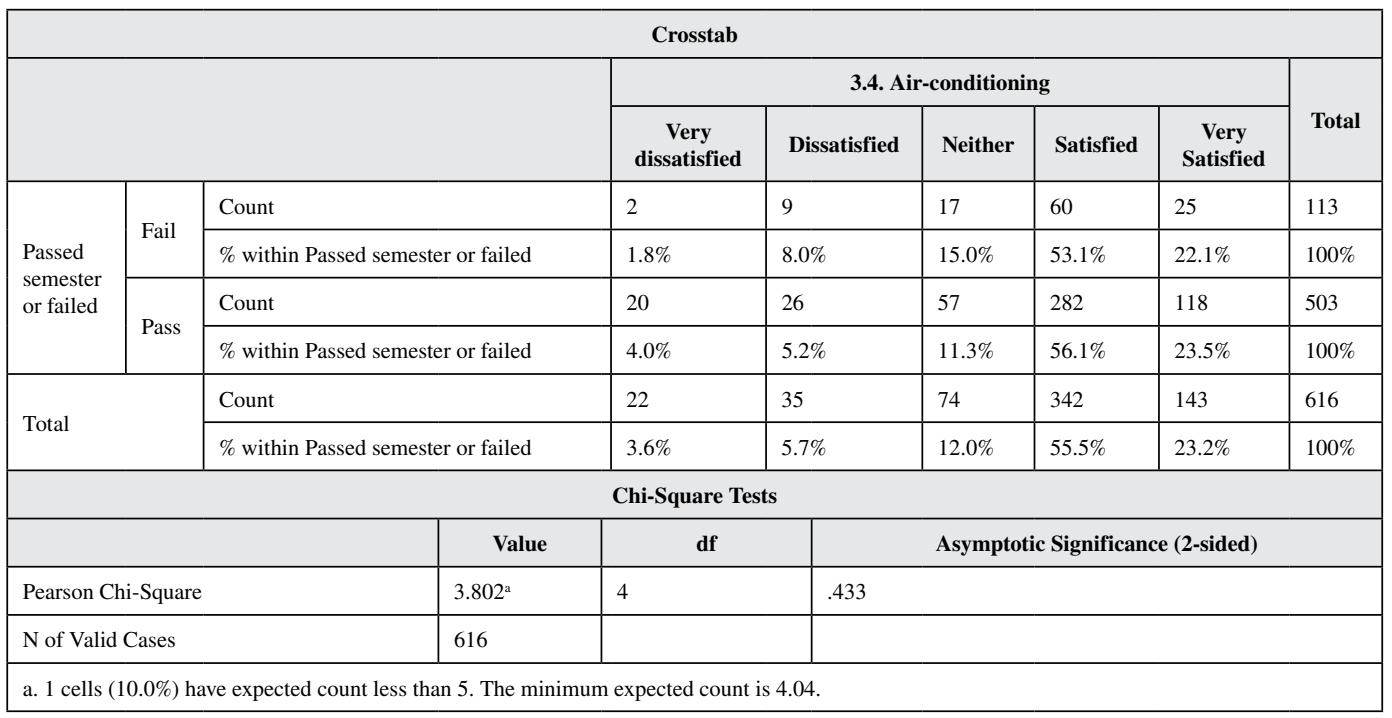

Table 15. Passed semester or failed * 3.5 . Lifts

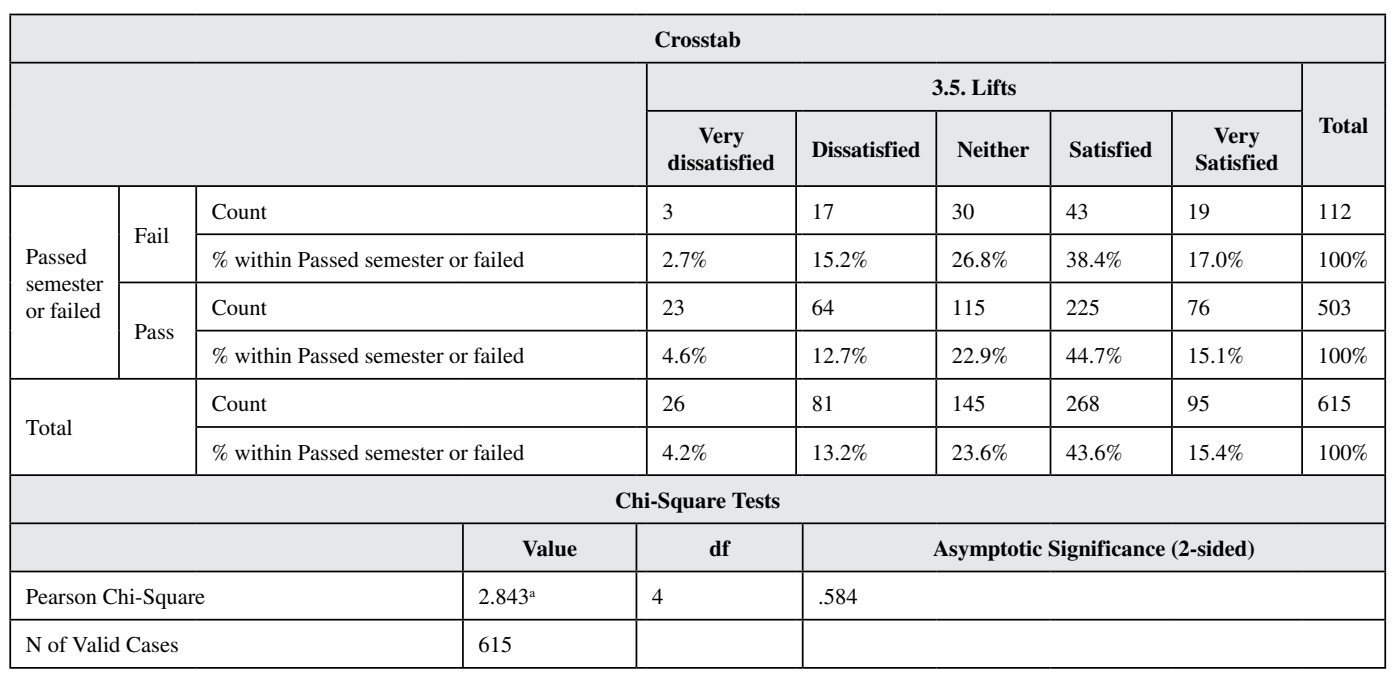

Table 19 reveals that the majority of the students who passed or failed at $49.2 \%$ and $48 \%$ respectively, will definitely recommend the university library to other students.

\section{CONCLUSION AND RECOMMENDATION}

\section{Conclusion}

The majority of the students are satisfied with the library services. However, satisfaction varies (based on academic performance) according to age and access to textbooks on the library shelves. 
Table 16. Passed semester or failed * 3.6. Overnight Study Area

\begin{tabular}{|c|c|c|c|c|c|c|c|c|c|}
\hline \multicolumn{10}{|c|}{ Crosstab } \\
\hline & & & & \multicolumn{5}{|c|}{ 3.6. Overnight Study Area } & \multirow[b]{2}{*}{ Total } \\
\hline & & & & $\begin{array}{c}\text { Very } \\
\text { dissatisfied }\end{array}$ & Dissatisfied & Neither & Satisfied & $\begin{array}{c}\text { Very } \\
\text { Satisfied }\end{array}$ & \\
\hline \multirow{4}{*}{$\begin{array}{l}\text { Passed } \\
\text { semester or } \\
\text { failed }\end{array}$} & \multirow[b]{2}{*}{ Fail } & \multicolumn{2}{|l|}{ Count } & 10 & 22 & 33 & 33 & 14 & 112 \\
\hline & & \multicolumn{2}{|l|}{$\begin{array}{l}\% \text { within Passed semester } \\
\text { or failed }\end{array}$} & $8.9 \%$ & $19.6 \%$ & $29.5 \%$ & $29.5 \%$ & $12.5 \%$ & $100 \%$ \\
\hline & \multirow[b]{2}{*}{ Pass } & \multicolumn{2}{|l|}{ Count } & 46 & 61 & 150 & 163 & 62 & 482 \\
\hline & & \multicolumn{2}{|l|}{$\begin{array}{l}\% \text { within Passed semester } \\
\text { or failed }\end{array}$} & $9.5 \%$ & $12.7 \%$ & $31.1 \%$ & $33.8 \%$ & $12.9 \%$ & $100 \%$ \\
\hline \multirow{2}{*}{\multicolumn{2}{|c|}{ Total }} & \multicolumn{2}{|l|}{ Count } & 56 & 83 & 183 & 196 & 76 & 594 \\
\hline & & \multicolumn{2}{|l|}{$\begin{array}{l}\% \text { within Passed semester } \\
\text { or failed }\end{array}$} & $9.4 \%$ & $14.0 \%$ & $30.8 \%$ & $33.0 \%$ & $12.8 \%$ & $100 \%$ \\
\hline \multicolumn{10}{|c|}{ Chi-Square Tests } \\
\hline & & & \multicolumn{2}{|c|}{ Value } & Df & \multicolumn{4}{|c|}{ Asymptotic Significance (2-sided) } \\
\hline \multicolumn{3}{|c|}{ Pearson Chi-Square } & \multicolumn{2}{|c|}{$3.824^{\mathrm{a}}$} & & \multicolumn{4}{|l|}{.430} \\
\hline \multicolumn{3}{|c|}{$\mathrm{N}$ of Valid Cases } & \multicolumn{2}{|c|}{594} & & & & & \\
\hline
\end{tabular}

Table 17. Passed semester or failed * 3.7. Signage (design or use of signs and symbols)

\begin{tabular}{|c|c|c|c|c|c|c|c|c|c|}
\hline \multicolumn{10}{|c|}{ Crosstab } \\
\hline & & & \multicolumn{6}{|c|}{ 3.7. Signage (design or use of signs and symbols) } & \multirow[b]{2}{*}{ Total } \\
\hline & & & & $\begin{array}{c}\text { Very } \\
\text { dissatisfied }\end{array}$ & Dissatisfied & Neither & Satisfied & $\begin{array}{c}\text { Very } \\
\text { Satisfied }\end{array}$ & \\
\hline \multirow{4}{*}{$\begin{array}{l}\text { Passed } \\
\text { semester or } \\
\text { failed }\end{array}$} & \multirow[b]{2}{*}{ Fail } & \multicolumn{2}{|l|}{ Count } & 0 & 7 & 45 & 45 & 14 & 111 \\
\hline & & \multicolumn{2}{|l|}{$\begin{array}{l}\% \text { within Passed } \\
\text { semester or failed }\end{array}$} & $0.0 \%$ & $6.3 \%$ & $40.5 \%$ & $40.5 \%$ & $12.6 \%$ & $100 \%$ \\
\hline & \multirow[b]{2}{*}{ Pass } & Count & & 14 & 28 & 154 & 242 & 56 & 494 \\
\hline & & \multicolumn{2}{|l|}{$\begin{array}{l}\% \text { within Passed } \\
\text { semester or failed }\end{array}$} & $2.8 \%$ & $5.7 \%$ & $31.2 \%$ & $49.0 \%$ & $11.3 \%$ & $100 \%$ \\
\hline \multirow{2}{*}{\multicolumn{2}{|c|}{ Total }} & \multicolumn{2}{|l|}{ Count } & 14 & 35 & 199 & 287 & 70 & 605 \\
\hline & & \multicolumn{2}{|l|}{$\begin{array}{l}\% \text { within Passed } \\
\text { semester or failed }\end{array}$} & $2.3 \%$ & $5.8 \%$ & $32.9 \%$ & $47.4 \%$ & $11.6 \%$ & $100 \%$ \\
\hline \multicolumn{10}{|c|}{ Chi-Square Tests } \\
\hline & & & \multicolumn{2}{|c|}{ Value } & df & \multicolumn{4}{|c|}{ Asymptotic Significance (2-sided) } \\
\hline \multicolumn{3}{|c|}{ Pearson Chi-Square } & \multicolumn{2}{|c|}{$7.118^{\mathrm{a}}$} & & \multicolumn{4}{|l|}{.130} \\
\hline \multicolumn{3}{|c|}{$\mathrm{N}$ of Valid Cases } & \multicolumn{2}{|l|}{605} & & & & & \\
\hline
\end{tabular}

This is because the age and student academic performance are negatively associated, hence, as age increases, the academic performance declines.

It is important for libraries to ensure that textbooks are easily accessible on the library shelves. Students who easily got access to their prescribed text books were associated with higher academic performance as most of them passed their semester one examinations. It was also concluded that frequency of library use, gender, year of study do not influence the academic performance of students. 
Table 18. Passed semester or failed * 3.8 . Overall, I always have a positive experience in the library

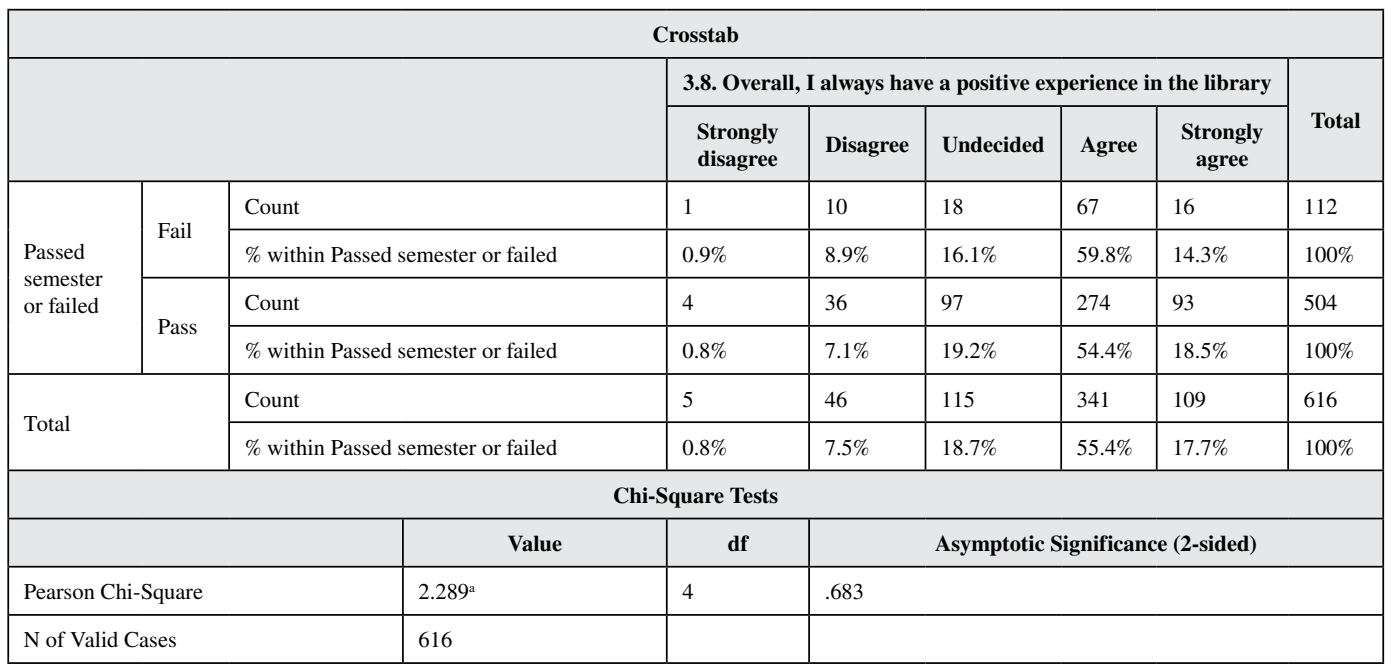

Table 19. Passed semester or failed * 3.9 . Would you recommend the Library to other students?

\begin{tabular}{|c|c|c|c|c|c|c|c|c|c|}
\hline \multicolumn{10}{|c|}{ Crosstab } \\
\hline & & & & \multicolumn{5}{|c|}{ 3.9. Would you recommend the Library to other students? } & \multirow[b]{2}{*}{ Total } \\
\hline & & & & $\begin{array}{c}\text { Definitely } \\
\text { not }\end{array}$ & $\begin{array}{c}\text { Probably } \\
\text { not }\end{array}$ & Probably & $\begin{array}{c}\text { Very } \\
\text { probably }\end{array}$ & Definitely & \\
\hline \multirow{4}{*}{$\begin{array}{l}\text { Passed } \\
\text { semester or } \\
\text { failed }\end{array}$} & \multirow[b]{2}{*}{ Fail } & \multicolumn{2}{|l|}{ Count } & 3 & 3 & 27 & 19 & 48 & 100 \\
\hline & & \multicolumn{2}{|c|}{$\begin{array}{l}\% \text { within Passed semester or } \\
\text { failed }\end{array}$} & $3.0 \%$ & $3.0 \%$ & $27.0 \%$ & $19.0 \%$ & $48.0 \%$ & $100.0 \%$ \\
\hline & \multirow[b]{2}{*}{ Pass } & \multicolumn{2}{|l|}{ Count } & 8 & 10 & 112 & 100 & 223 & 453 \\
\hline & & \multicolumn{2}{|c|}{$\begin{array}{l}\% \text { within Passed semester or } \\
\text { failed }\end{array}$} & $1.8 \%$ & $2.2 \%$ & $24.7 \%$ & $22.1 \%$ & $49.2 \%$ & $100.0 \%$ \\
\hline \multirow{2}{*}{\multicolumn{2}{|c|}{ Total }} & Count & & 11 & 13 & 139 & 119 & 271 & 553 \\
\hline & & \multicolumn{2}{|c|}{$\begin{array}{l}\% \text { within Passed semester or } \\
\text { failed }\end{array}$} & $2.0 \%$ & $2.4 \%$ & $25.1 \%$ & $21.5 \%$ & $49.0 \%$ & $100.0 \%$ \\
\hline \multicolumn{10}{|c|}{ Chi-Square Tests } \\
\hline & & & \multicolumn{2}{|c|}{ Value } & Df & \multicolumn{4}{|c|}{ Asymptotic Significance (2-sided) } \\
\hline \multicolumn{3}{|c|}{ Pearson Chi-Square } & \multicolumn{2}{|c|}{$1.400^{\mathrm{a}}$} & & \multicolumn{4}{|l|}{.844} \\
\hline \multicolumn{2}{|c|}{$\mathrm{N}$ of Valid Cases } & & 53 & & & & & & \\
\hline
\end{tabular}

\section{Recommendation}

It is important to establish a collaboration between the teaching and library staff in order to nurture students' learning development and augment their learning achievement (Mahwasane, 2017). Academic staff should provide updated lists of academic materials, and the library staff should ensure that such materials are easily accessible to students. Students should have access to relevant and adequate materials in order for them to improve their academic performance.

In line with a study by Shrestha (2008) who discovered that in "today's fast paced world the desire for expediency has promoted students to place a premium on information that can be found 
easily and quickly." The library department is encouraged to invest more in e-journals, eBooks and other academic library online subscription services in order to meet the needs of the students.

The library should have an automated system which links library usage to students' academic performance. Such a system will enable the library staff to determine which services are mostly important to students to enhance their academic performance.

Further research can involve a quasi-experimental research in which the students' nature of interaction with the university librarians is surveyed, and the results linked to the students' academic performance.

\section{ACKNOWLEDGMENT}

The author would like to acknowledge the support provided by students in terms of participating in the study as without their participation the study could not have been successfully completed. The author further thanks the university library staff for providing some of the study research questions. 


\section{REFERENCES}

Aghojare, B., Ferdinand, A. O., \& Patrick, L. O. (2015). Assess Users' Satisfaction on Academic Library Performance: A Study. International Journal of Academic Research and Reflection, 3(5). https://pdfs. semanticscholar.org/eaed/9c742eba52b49d46d1ea22b3f260db8c78c8.pdf

Ateboh, A. B., \& Tiemo, A. P. (2016). Users' Satisfaction with Library Information Resources and Services: A Case Study College of Health Sciences Library Niger Delta University, Amassoma, Nigeria. Journal of Education and Practice, 7(16). https://files.eric.ed.gov/fulltext/EJ1105267.pdf

Brown, K., \& Malenfant, K.J. (2015). Academic Library Contributions to Student Success: Documented Practices from the Field. Retrieved from http://www.ala.org/acrl/sites/ala.org.acrl/files/content/issues/value/ contributions_report.pdf

Confessore, G. J., Lai, M. S., Ng, F. S., \& Zakaria, R. (2016). A study of time use and academic achievement among secondary-school students in the state of Kelantan, Malaysia. International Journal of Adolescence and Youth, 21(4), 433-448. doi:10.1080/02673843.2013.862733

de Jager, K. (1997). Library use and academic achievement. Sajllis Journal, 65(1). Retrieved from http://citeseerx. ist.psu.edu/viewdoc/download?doi=10.1.1.850.4302\&rep=rep1\&type $=$ pdf

Fluid Surveys. (2014). Calculating the Right Survey Sample Size. Retrieved from http://fluidsurveys.com/ university/calculating-right-survey-sample-size/

Gbemi-Ogunleye, P. (2016). Library Use and Students Academic Achievement: Implication for Counseling. Information and Knowledge Management, 6(2). Retrieved from https://pdfs.semanticscholar.org/735c/3c1911 0bca9ec635c65ae443cdb7870bd219.pdf

Ida, L. (2016). Influence of Library Services on Students Academic Performance in an Ordinary Certificate of Secondary Education Examination in Mtwara Mikindani Municipality, Tanzania (Masters thesis, University of Tanzania, Tanzania). Retrieved from http://repository.out.ac.tz/1822/1/DISSERTATION_-LEO_IDA_FINAL.pdf

Laltlanmawii, R., \& Verma, M. K. (2016). Use and User's Satisfaction on Library Resources and Services by U.G. Students of Government Hrangbana College, Aizawl: A Study. Journal of Advances in Library and Information Science, 5(1), 18-23. https://www.researchgate.net/publication/298258156_Use_and_User's_Satisfaction_on_ Library_Resources_and_Services_by_UG_Students_of_Government_Hrangbana_College_Aizawl_A_Study

Lonsdale, M. (2003). Impact of School Libraries on Student Achievement: A Review of the Research. Retrieved from https://www.researchgate.net/publication/234608717_Impact_of_School_Libraries_on_Student_ Achievement_A_Review_of_the_Research

Luther, J. (2008). University investment in the library: What's the return? A case study at the University of Illinois at Urbana-Champaign. Elsevier.

Mahwasane, N. P. (2017). The Influence of School Library Resources on Students' Learning: A Concept Paper. International Journal of Educational Sciences, 17(1-3), 190-196. doi:10.1080/09751122.2017.1305739

Nawarathne, I. M., \& Singh, A. P. (2013). Users' Satisfaction of the Academic Library Services in Sri Lanka. Journal of Library and Information Science, 7(2), 103-112. doi:10.5958/j.0975-6922.7.2.016

Nazy, L., Socheata, V., Sopanha, M., \& Vichea, L. (2018). The Impact of Library Usage on UC Students' Academic Performance. Retrieved from https://uc.edu.kh/userfiles/image/2018/The_Impact_of_Library_Usage_on_UC.pdf

Niskala, R. (2008). The Need and Use of Community Library Services in Namibia (Masters thesis, University of Tampere, Finland). Retrieved from https://trepo.tuni.fi/bitstream/handle/10024/79357/gradu02836. pdf? sequence $=1 \&$ isAllowed $=y$

Ramsden, B., \& Stone, G. (2013). Library Impact Data Project: Looking for the Link between Library Usage and Student Attainment. Retrieved from https://crl.acrl.org/index.php/crl/article/viewFile/16337/17783

Shrestha, N. (2008). A Study on Student's Use of Library Resources and Self-Efficacy (Masters thesis, Tribhuvan University, Kirtipur, Katmandu, Nepal). Retrieved from http://eprints.rclis.org/22623/1/NinaShrestha.pdf 
Smith, S. (2013). Determining Sample Size: How to Ensure You Get the Correct Sample Size. Retrieved from https://www.qualtrics.com/blog/determining-sample-size/

Sulit-Leonen, M. (2012). An Analysis of the relationship between Library Use and Student's Achievement at a Master Level, Dubai (Masters thesis, The British University in Dubai (BUiD), Dubai). Retrieved from https:// pdfs.semanticscholar.org/a6cf/1f331042c5a4e8cdcda77ea7a5aa962da5bc.pdf

Wells, J. (1995). The Influence of Library Usage on Undergraduate Academic Success. Australian Academic and Research Libraries, 26(2), 121-128. doi:10.1080/00048623.1995.10754923 